\title{
Contribution of folic acid-fortified foods to fertile women's folate Recommended Nutrient Intake through breakfast simulation models
}

\author{
María de Lourdes Samaniego-Vaesken*, Elena Alonso-Aperte and \\ Gregorio Varela-Moreiras \\ Departamento de Ciencias Farmacéuticas y de la Salud, Facultad de Farmacia, Universidad CEU San Pablo, \\ Ctra. Boadilla del Monte Km: 5.300, 28668 Boadilla del Monte, Madrid, Spain
}

Submitted 6 September 2013: Final revision received 6 October 2014: Accepted 9 October 2014: First published online 28 November 2014

\begin{abstract}
Objective: To assess the potential contribution of foods fortified with folic acid (FA) to target population intakes when included as part of a healthy breakfast.

Design: Breakfast models aligned with the Spanish Dietary Guidelines were studied using the recommended, average and 95th percentile of serving sizes consumed by women of childbearing age. Food composition data were obtained from a database including FA analytical data from sixty-eight products and the Spanish food composition tables. Different scenarios were assessed with the inclusion of one, two or three FA-fortified products and with two different fortification levels: $\leq 33 \mu \mathrm{g} /$ serving (L1) and $\geq 70 \mu \mathrm{g} /$ serving (L4). FA contents provided by the different models for each scenario were compared with the Recommended Nutrient Intake (RNI) for folate and the Upper Level (UL) of intake for FA.

Setting: Madrid Region, Spain.

Subjects: Women aged 16-49 years were considered.

Results: Overall, simulation of ten breakfast models and three scenarios of product inclusion accounted for $20-25 \%$ of total daily energy recommendations for women. Unfortified breakfast models provided on average 4-23\% of the folate RNI. Inclusion of one L4 FA-fortified food contributed $20-60 \%$ of the RNI. Fortified yoghurt and milk had the highest FA contents per serving. Scenarios with two or three fortified products delivered $40-80 \%$ of the RNI. None of the evaluated models exceeded the FA UL.

Conclusions: At existing levels of FA fortification, inclusion of fortified products as part of a regular breakfast meal could positively impact the nutritional quality of women's diet without involving a risk of excessive FA exposure.
\end{abstract}

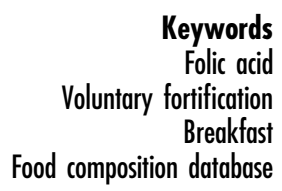

Keywords

rtification

Breakfast

Food composition database
Folate is the generic name commonly used to designate a group of water-soluble vitamers from B complex found naturally in foods ${ }^{(1)}$. Main dietary folate sources are green leafy vegetables, legumes, fruits, liver and yeast extract. Folate plays an essential role as a coenzyme in singlecarbon transfers, participating in the metabolism of amino acids and nucleic acids. Folic acid (FA) is the most oxidised and stable synthetic form of folate used in vitamin supplements and in food fortification. Since the 1990s it has been recognised that periconceptional FA supplementation can prevent neural tube defects, an important cause of perinatal mortality and infant paralysis ${ }^{(2,3)}$. As a result, a number of recommendations and actions were adopted in several countries to supplement fertile women and to increase the FA content in their diets. Food fortification is the practice of deliberately increasing the content of an essential micronutrient, i.e. vitamins and minerals, in a food so as to improve the nutritional quality of the food supply and provide a public health benefit with minimal risk to health ${ }^{(4)}$. Since 1998, mandatory fortification of enriched wheat flour and other enriched grain products with $\mathrm{FA}$ and $\mathrm{B}$ vitamins has been taking place in the USA and Canada, and at present is implemented in up to seventy-seven countries ${ }^{(5)}$. By this strategy, manufacturers are required to add regulated levels of FA to wheat flour and other grain products ${ }^{(6)}$. In Europe, however, safety concerns of a population-based exposure to high FA intakes have been the main reason to deny 
mandatory fortification ${ }^{(7)}$ and consequently in most European countries FA fortification takes place on a voluntary basis only. Voluntary fortification is the addition of micronutrients to food products by manufacturers at their own discretion. Fortified food groups and levels of FA addition can vary widely, as observed in The Netherlands $(15-500 \mu \mathrm{g} / 100 \mathrm{~g})^{(8)}$ and Spain $(15-1569 \mu \mathrm{g} / 100 \mathrm{~g} \text { or } 100 \mathrm{ml})^{(9)}$. The main type of products being fortified are ready-to-eat breakfast cereals (RTEC), non-alcoholic beverages, and milk and other milk products $^{(9)}$. Certainly, voluntarily FA-fortified products may help increase this vitamin's intake among the population, as they are usually its main dietary source ${ }^{(7)}$. However, since FA content data are still scarce in food composition tables and databases ${ }^{(10)}$, dietary folate assessment of the population can be inaccurate. For several years, our research group has been compiling and updating the first food composition database which includes FA-fortified products commercialised in Spain, as well as analysing the FA content in the main food groups ${ }^{(9,11)}$.

The Mediterranean diet comprises a high intake of major folate sources such as green leafy vegetables, fruits, legumes and nuts. This healthy food pattern, which is part of the Spanish culture and identity, has changed gradually over the last 40 years to a less balanced diet ${ }^{(12,13)}$. Moreover, recent dietary surveys conducted in Spain report that women of fertile age are not meeting their folate requirements from diet alone since the average dietary folate intake in women was estimated to be less than $60 \%$ of their recommended intake (i.e. Recommended Nutrient Intake (RNI) for folate) ${ }^{(12)}$. Conversely, pharmacological FA supplementation is the method of choice for European women who are planning a pregnancy and seek medical counselling $^{(7)}$. However, a recent survey that involved nineteen countries ( $n$ 22 925) including Spain found that a large proportion of women of childbearing age $(64 \%$ in Spain $v .83 \%$ Europe) were actually unaware that periconceptional FA supplementation could reduce the risk of birth defects ${ }^{(14)}$.

In the context of a healthy diet, breakfast is a common dietary habit in many cultures, although each country has its own unique characteristics. The traditional Spanish breakfast typically includes coffee, cocoa or tea with/without milk, a slice of bread with olive oil or tomato paste, pastries, cookies and, more recently, RTEC have become quite popular $^{(15)}$. Natural or commercial fruit juice may also be included. In addition, fruit intake is recommended, but compliance is low. Dairy products are highly accepted among the Spanish population, although a sharp decline in consumption has been observed in the last 10 years ${ }^{(16)}$. National dietary guidelines recommend inclusion of at least four different food groups for a nutritionally balanced breakfast $^{(15)}$. It is also recommended that breakfast should provide about $20-25 \%$ of the total daily energy intake ${ }^{(17)}$, but currently a high and increasing proportion of the population is skipping the habit of breakfast or at best including only one or two food groups ${ }^{(15)}$.
The main objective of the present study was to examine the contribution of a representative number of FA-fortified food products to the RNI for folate or exceeding the Upper Level (UL) of intake for FA among fertile women by the potential consumption of a typical breakfast meal.

\section{Materials and methods}

\section{Breakfast simulation model design}

Healthy breakfast models that included different combinations of food and beverage groups were selected from the national dietary guidelines ${ }^{(18)}$. Folate intakes were calculated on the basis of average recommended serving sizes and by adding the FA content from fortified foods to the unfortified natural folate content of each foodstuff. Sources of data were a food composition database, which included the analytical FA contents from sixty-eight products compiled and analysed by our group from 2006 to $2011^{(19)}$, and data from the Spanish food composition tables published by Moreiras et al. ${ }^{(20)}$. Simulation of ten breakfast models that reflected the different breakfast menus recommended within the Spanish Dietary Guidelines $^{(18)}$ and three scenarios of fortified product inclusion were evaluated (Table 1). Food and beverage groups included were grains and derivatives, milk and milk products, fats and oils, beverages (non-milk), fruits, tomatoes and sugar. FA-fortified products included were RTEC, cookies, whole milk, whole yoghurt and commercial fruit nectar (Table 1). First, the proportion of total daily recommended energy intake and the natural folate content of the unfortified breakfast models were calculated. These data were obtained from the Spanish food composition tables ${ }^{(20)}$. Then, the inclusion of combinations of one, two or three FA-fortified products, with two FA fortification levels according to European Regulation ${ }^{(21)}$, were used for each breakfast model. Analytical FA data from the sixty-eight fortified products were segmented into two fortification levels, calculated as a percentage of the Daily Reference Intake (DRI, $200 \mu \mathrm{g})^{(21)}$ for FA according to the manufacturer's recommended serving of each product (L1, $\leq 16 \%$ of the DRI or $\leq 33 \mu \mathrm{g} \mathrm{FA} /$ serving; $44, \geq 35 \%$ of the DRI or $\geq 70 \mu \mathrm{g} \mathrm{FA}$ /serving), reflecting lower and higher fortification levels available on the market. In addition, the average and 95th percentile (P95) of serving sizes consumed by women of childbearing age were used for assessing the FA UL ${ }^{(22)}$. Breakfast meals were evaluated using the energy and nutrient recommendations for women aged 16-49 years, folate (RNI, $400 \mu \mathrm{g} / \mathrm{d}$ ) and the FA UL $(1000 \mu \mathrm{g} / \mathrm{d})^{(23,24)}$.

\section{Folic acid-fortified product sampling}

Each food product was acquired in duplicate at supermarkets and retail stores from the Madrid Region. Food samples were RTEC ( $n$ 25), cookies ( $n$ 10), yoghurt (whole; $n$ 5), cow's milk (whole; $n$ 25) and fruit nectar ( $n$ 3). 
Table 1 Breakfast models and scenarios for folic acid (FA)-fortified food intake simulation

\begin{tabular}{|c|c|c|c|c|}
\hline \multirow[b]{2}{*}{ Breakfast model } & \multirow[b]{2}{*}{ Total food products included } & \multicolumn{3}{|c|}{ Scenarios: number of FA-fortified foodstuffs included } \\
\hline & & 1 & 2 & 3 \\
\hline A & $\begin{array}{l}\text { Natural orange juice } \\
\text { Cow's milk (whole) } \\
\text { White bread (toasted) } \\
\text { Olive oil } \\
\text { Sugar }\end{array}$ & Cow's milk (whole) & - & - \\
\hline B & $\begin{array}{l}\text { Natural orange juice } \\
\text { Cow's milk (whole) } \\
\text { White bread (toasted) } \\
\text { Jam } \\
\text { Butter } \\
\text { Sugar }\end{array}$ & Cow's milk (whole) & $\begin{array}{l}\text { Cow's milk (whole) } \\
\text { Fruit nectar (sweetened) }\end{array}$ & - \\
\hline $\mathrm{C}$ & $\begin{array}{l}\text { Natural orange juice } \\
\text { Cow's milk (whole) } \\
\text { Cookies } \\
\text { Cocoa (soluble) }\end{array}$ & Cookies & $\begin{array}{l}\text { Cow's milk (whole) } \\
\text { Cookies }\end{array}$ & $\begin{array}{l}\text { Cow's milk (whole) } \\
\text { Cookies } \\
\text { Fruit nectar (sweetened) }\end{array}$ \\
\hline $\mathrm{D}$ & $\begin{array}{l}\text { Natural orange juice } \\
\text { Cow's milk (whole) } \\
\text { Breakfast cereals } \\
\text { Sugar }\end{array}$ & Breakfast cereals & $\begin{array}{l}\text { Cow's milk (whole) } \\
\text { Breakfast cereals }\end{array}$ & $\begin{array}{l}\text { Cow's milk (whole) } \\
\text { Breakfast cereals } \\
\text { Fruit nectar (sweetened) }\end{array}$ \\
\hline $\mathrm{E}$ & $\begin{array}{l}\text { Fruit nectar (sweetened) } \\
\text { Cow's milk (whole) } \\
\text { White bread (toasted) } \\
\text { Tomato, natural } \\
\text { Sugar }\end{array}$ & Fruit nectar (sweetened) & - & - \\
\hline $\mathrm{F}$ & $\begin{array}{l}\text { Yoghurt (whole) } \\
\text { White loaf bread } \\
\text { Butter } \\
\text { Kiwi fruit }\end{array}$ & Yoghurt (whole) & - & - \\
\hline $\mathrm{G}$ & $\begin{array}{l}\text { Yoghurt (whole) } \\
\text { Assorted nuts } \\
\text { Cookies } \\
\text { Mandarin }\end{array}$ & Cookies & $\begin{array}{l}\text { Yoghurt (whole) } \\
\text { Cookies }\end{array}$ & - \\
\hline $\mathrm{H}$ & $\begin{array}{l}\text { Yoghurt } \\
\text { Apple } \\
\text { Breakfast cereals }\end{array}$ & Breakfast cereals & $\begin{array}{l}\text { Breakfast cereals } \\
\text { Yoghurt (whole) }\end{array}$ & - \\
\hline I & $\begin{array}{l}\text { Cow's milk (whole) } \\
\text { Cocoa (soluble) } \\
\text { Doughnuts or pastries } \\
\text { Sugar }\end{array}$ & Cow's milk (whole) & - & - \\
\hline $\mathrm{J}$ & $\begin{array}{l}\text { Cow's milk (whole) } \\
\text { White bread (toasted) } \\
\text { Tomato (natural) } \\
\text { Sugar }\end{array}$ & Cow's milk (whole) & - & - \\
\hline
\end{tabular}

Samples were stored at room or refrigeration temperature until individual processing (grinding and/or homogenising) and finally aliquots were flushed with nitrogen and frozen at $-20^{\circ} \mathrm{C}$. On the day of analysis, samples were thawed, weighed (0.5-1 g diluted to a final $15 \mathrm{ml}$ volume), extracted, purified and analysed in duplicate as described in the following section.

\section{Folic acid quantification in fortified food products}

The analysis of FA-fortified food products involved the following steps: (i) tri-enzyme extraction from the food matrix $^{(25)}$; (ii) purification and concentration by affinity chromatography with folate-binding protein; and (iii) finally separation and quantification by reversed-phase HPLC with UV detection ${ }^{(26,27)}$. A Standard Reference Material (SRM 1846) and an International Standard ${ }^{(28,29)}$ were used throughout the analysis to test for accuracy. FA was used as standard and obtained from Sigma (Spain) in analytical grade. Standard stock solutions were prepared separately in $1 \%(\mathrm{w} / \mathrm{v})$ ascorbic acid, protected from light and stored at $-80^{\circ} \mathrm{C}$. Concentrations were calculated by measuring FA absorbance at $k=282 \mathrm{~nm}$ with a spectrophotometer (Beckman DU-650, EE UU) and by molar extinction coefficient (27 600 litres/mol per $\mathrm{cm})^{(1)}$.

\section{Results}

Average FA fortification levels were calculated after affinity chromatography-HPLC analysis of sixty-eight food products (Table 2), yielding four fortification levels from which the highest and lowest (1 and 4; L1 and L4) were 
Table 2 Folic acid (FA) fortification levels and energy content of the different food groups

\begin{tabular}{|c|c|c|c|c|c|c|c|c|}
\hline \multirow[b]{3}{*}{ Food group } & \multirow{3}{*}{$\begin{array}{l}\text { Fortification } \\
\text { level }^{*}\end{array}$} & \multirow[b]{3}{*}{$n \dagger$} & \multirow{3}{*}{$\begin{array}{l}\text { Recommended } \\
\text { serving }(\mathrm{g} \text { or } \mathrm{ml}) \ddagger\end{array}$} & \multirow{2}{*}{\multicolumn{2}{|c|}{$\begin{array}{c}\text { Analytical data } \\
\text { FA ( } \begin{array}{c}\mu \mathrm{g} / 100 \mathrm{~g} \text { or } \\
100 \mathrm{ml})\end{array}\end{array}$}} & \multicolumn{3}{|c|}{ Food composition tables§ } \\
\hline & & & & & & \multirow{2}{*}{$\begin{array}{l}\begin{array}{l}\text { Folate }(\mu \mathrm{g} / 100 \mathrm{~g} \text { or } 100 \mathrm{ml}) \\
\text { (unfortified products) }\end{array} \\
\text { Average }\end{array}$} & \multicolumn{2}{|c|}{$\begin{array}{c}\text { Energy }(\mathrm{kJ} / 100 \mathrm{~g} \text { or } \\
100 \mathrm{ml})\end{array}$} \\
\hline & & & & Average & SD & & Average & SD \\
\hline \multirow{2}{*}{$\begin{array}{l}\text { Ready-to-eat breakfast } \\
\text { cereals }\end{array}$} & L1 & 11 & $30-40$ & $69 \cdot 4$ & 14.6 & $-\|$ & 1507 & 64.6 \\
\hline & L4 & 15 & & $280 \cdot 6$ & $62 \cdot 2$ & & 1503 & 47.6 \\
\hline \multirow[t]{2}{*}{ Cookies } & L1 & 8 & $25-45$ & 60.5 & $15 \cdot 2$ & $-\|$ & 1909 & 28.5 \\
\hline & L3 & 2 & & 186 & 0.5 & & 1792 & 34 \\
\hline \multirow[t]{2}{*}{ Milk (whole) } & L3 & 2 & 200 & $34 \cdot 2$ & 0.4 & 12.5 & 270 & $7 \cdot 8$ \\
\hline & L4 & 23 & & 53.9 & $22 \cdot 6$ & & 216 & 17.5 \\
\hline \multirow[t]{2}{*}{ Yoghurt (whole) } & L1 & 2 & 125 & $27 \cdot 8$ & 0.1 & $16 \cdot 9$ & 237 & $6 \cdot 4$ \\
\hline & L4 & 3 & & $176 \cdot 6$ & 29.4 & & 190 & 28.3 \\
\hline Fruit nectar (sweetened) & L4 & 3 & 200 & 25.5 & 3.62 & Natural orange juice: 74 & 150 & $13 \cdot 8$ \\
\hline
\end{tabular}

*L1 (level 1), $\leq 33 \mu \mathrm{g} \mathrm{FA/serving} \mathrm{(} \leq 16 \%$ of the Daily Reference Intake (DRI, $200 \mu \mathrm{g}$ ) for FA per serving as declared by manufacturers); L3 (level 3 ), $51-69 \mu \mathrm{g}$ $\mathrm{FA} /$ serving ( $26-34 \%$ of the DRI); L4 (level 4$), \geq 70 \mu \mathrm{g} \mathrm{FA} /$ serving $\left(\geq 35 \%\right.$ of the DRI) ${ }^{(21)}$.

$\dagger n$ is the number of products from each fortification level.

†Serving sizes recommended for adults ${ }^{(18)}$.

$\S$ Spanish food composition table by Moreiras et al. ${ }^{(20)}$

IIData were not available for these products.

studied. For whole milk, higher fortification levels were obtained analytically; thus L1 was non-existent and we used level 3 (L3; 26-34\% of the DRI $=51-69 \mu \mathrm{g}$ FA/serving). For cookies, analysed fortification levels were lower: L1 and L3 only; and for fruit nectar only L4 was obtained (Table 2). Natural folate content data (unfortified values) for these products as compiled from the food composition tables ${ }^{(20)}$ are also presented (Table 2).

Breakfast scenarios including one fortified product or the combination of two or three different FA-fortified items, at two fortification levels (L1 and L4), were studied for adult women (16-49 years) as a percentage of their recommended folate intake (RNI for the Spanish population $^{(23)}$ ) and the FA UL ${ }^{(24)}$. On average, most of models accounted for $20-25 \%$ of total daily energy recommendations (RNI; $9146 \cdot 4-9627 \cdot 8 \mathrm{~kJ} / \mathrm{d} \quad(2185-2300 \mathrm{kcal} / \mathrm{d})$ ), whereas natural folate content was on average $4-23 \%$ of women's recommended folate intake (16-92 $\mu \mathrm{g}$ of FA).

Figure 1 shows the contribution of FA-fortified products to each breakfast model's natural folate content. Breakfast model F, which included L4-fortified whole-milk yoghurt, unfortified bread and butter and a piece of fruit, provided the highest percentage, $67.4 \%$ of the folate RNI (269.6 $\mu \mathrm{g}$ of FA), followed by breakfast models $\mathrm{A}$ and $\mathrm{B}$, which included FA-fortified whole cow's milk, sugar and natural orange juice plus bread and olive oil (A) or bread, butter and jam (B). The latter two models include orange juice which is a major source of natural folate, providing $23 \%$ of the daily RNI per serving ( $92 \mu \mathrm{g}$ of FA). Based on our data, L4-fortified whole-milk yoghurt was the highest FA source, followed by L4-fortified whole milk. The major increase from an unfortified breakfast was observed for model J (whole milk with sugar and toasted white bread with natural tomato), which provided only $5 \%$ of the folate RNI when unfortified ( $20 \mu \mathrm{g}$ of FA), but when a serving of fortified whole milk was included it increased its contribution up to $40.5 \%$ of the RNI (162 $\mu \mathrm{g}$ of FA). Overall, the inclusion of one product at the lowest FA fortification level (L1) accounted for 13-29\% of women's daily RNI for folate (52-116 $\mu \mathrm{g}$ of FA), while the addition of one product at the highest fortification level (L4) provided an average of $20-60 \%$ of the RNI ( $80-240 \mu \mathrm{g}$ of FA; Fig. 1). Models B, $\mathrm{D}, \mathrm{G}$ and $\mathrm{H}$, including two fortified products, whole milk or whole-milk yoghurt plus fruit nectar, RTEC or cookies (Table 1 ), contributed $\geq 80 \%$ of the RNI ( $\geq 320 \mu \mathrm{g}$ of FA; Fig. 2). Models $C$ and $D$, with three fortified products each, accounted for $70-75 \%$ of the RNI (280-300 $\mu$ g of FA; Fig. 2). At recommended, average and $P 95$ serving sizes, none of the scenarios exceeded the FA UL for adults $(1000 \mu \mathrm{g} / \mathrm{d}$; Fig. 3). The highest FA levels were observed when three L4-fortified products, fruit nectar, whole milk and cookies, were consumed at P95 (37\% of the UL, Scenario 3).

\section{Discussion}

Daily breakfast consumption has been acknowledged to contribute significantly to overall diet nutrient adequacy ${ }^{(30)}$. Other suggested benefits are related to better weight control and intellectual/cognitive performance, and also to the creation and/or consolidation of adequate dietary habits. Our results show that at existing levels of FA fortification available on the Spanish market, the combined inclusion of up to three different products as part of a breakfast meal could have a positive impact on fertile women's dietary folate intakes, without exceeding the UL of FA intake. All food products included in the breakfast 


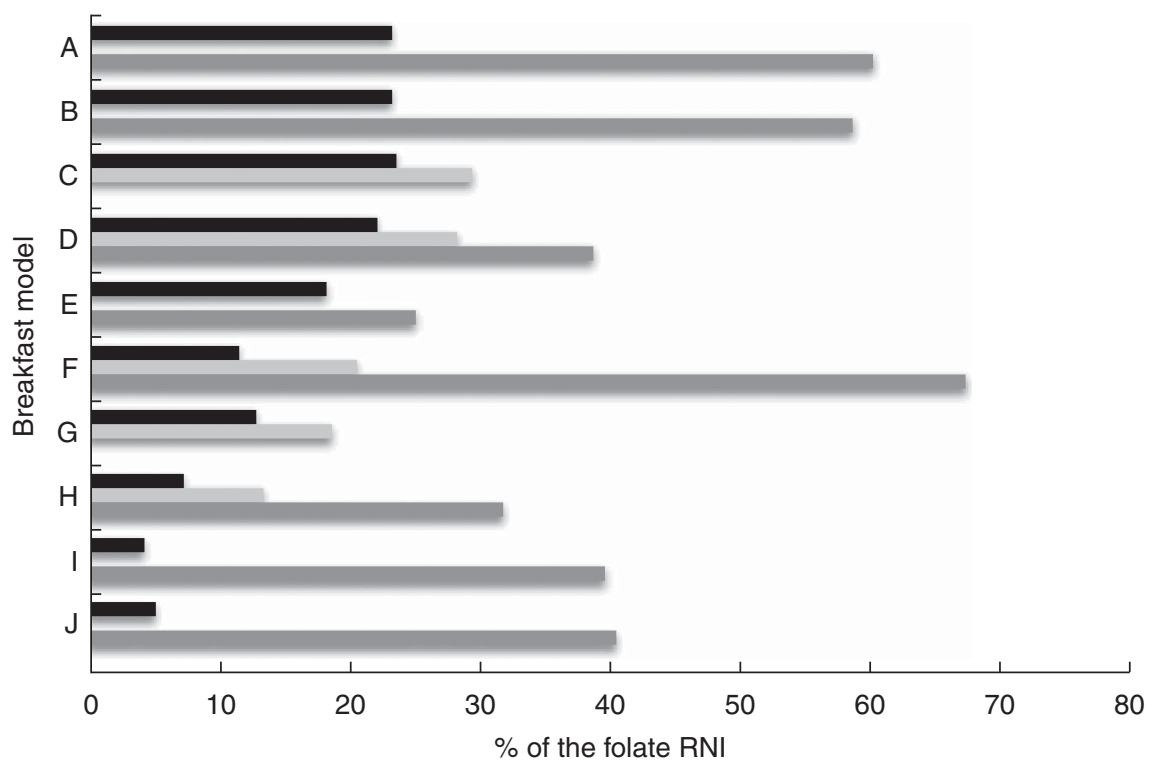

Fig. 1 Scenario 1: effect of the inclusion of one food fortified with folic acid (FA) in different breakfast models on the percentage of the Recommended Nutrient Intake (RNI) for folate $(400 \mu \mathrm{g} / \mathrm{d})$ provided in breakfast, according to fortification level ( L, L1; , L4), among women of childbearing age (16-49 years), Madrid Region, Spain. Unfortified, natural folate content per serving; L1 (level 1), $\leq 33 \mu \mathrm{g} \mathrm{FA/serving} \mathrm{(} \leq 16 \%$ of the Daily Reference Intake (DRI, $200 \mu \mathrm{g})$ for FA per serving as declared by manufacturers); L4 (level 4), $\geq 70 \mu \mathrm{g} \mathrm{FA} /$ serving ( $\geq 35 \%$ of the DRI) ${ }^{(21)}$. For breakfast models $\mathrm{A}, \mathrm{B}, \mathrm{C}, \mathrm{D}, \mathrm{I}$ and $\mathrm{J}$ including whole milk, no L1 was obtained and L3 (level 3) is represented instead: L3, 51-69 $\mu \mathrm{g} \mathrm{FA/serving} \mathrm{(26-34} \mathrm{\%} \mathrm{of} \mathrm{the} \mathrm{DRI).} \mathrm{For} \mathrm{C} \mathrm{and} \mathrm{D,} \mathrm{fruit} \mathrm{nectar}$ only provided L4

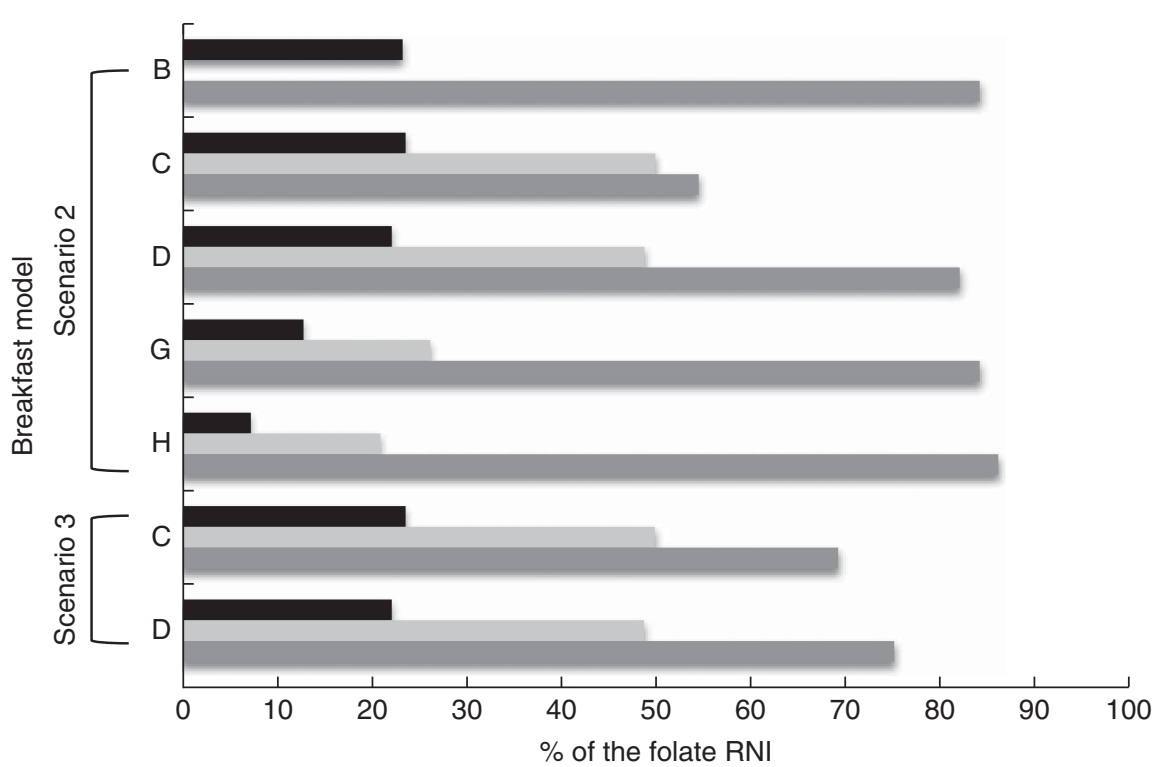

Fig. 2 Scenarios 2 and 3: effect of the inclusion of two or three foods fortified with folic acid (FA) in different breakfast models on the percentage of the Recommended Nutrient Intake (RNI) for folate $(400 \mu \mathrm{g} / \mathrm{d})$ provided in breakfast, according to fortification level ( $\square$, unfortified; , L1; , L4), among women of childbearing age (16-49 years), Madrid Region, Spain. Unfortified, natural folate content per serving; L1 (level 1), $\leq 33 \mu \mathrm{g} \mathrm{FA/serving} \mathrm{(} \leq 16 \%$ of the Daily Reference Intake (DRI, $200 \mu \mathrm{g})$ for FA per serving as declared by manufacturers); L4 (level 4$), \geq 70 \mu \mathrm{g} \mathrm{FA} /$ serving ( $\geq 35 \%$ of the DRI) ${ }^{(21)}$. For breakfast models B and C including whole milk, no L1 was obtained and L3 (level 3) is represented instead: L3, 51-69 $\mu$ g FA/serving (26-34\% of the DRI). For C and D, fruit nectar only provided L4

models are consumed regularly, to different extents, by the Spanish population ${ }^{(12)}$. It seems feasible to state that a breakfast meal consistent with Spanish Dietary Guidelines, in terms of energy content and food group inclusion, could also increase FA intakes when fortified products are included. The breakfast meal is considered of importance among the Spanish population not only nutritionally but also culturally; however, recent surveys show that 


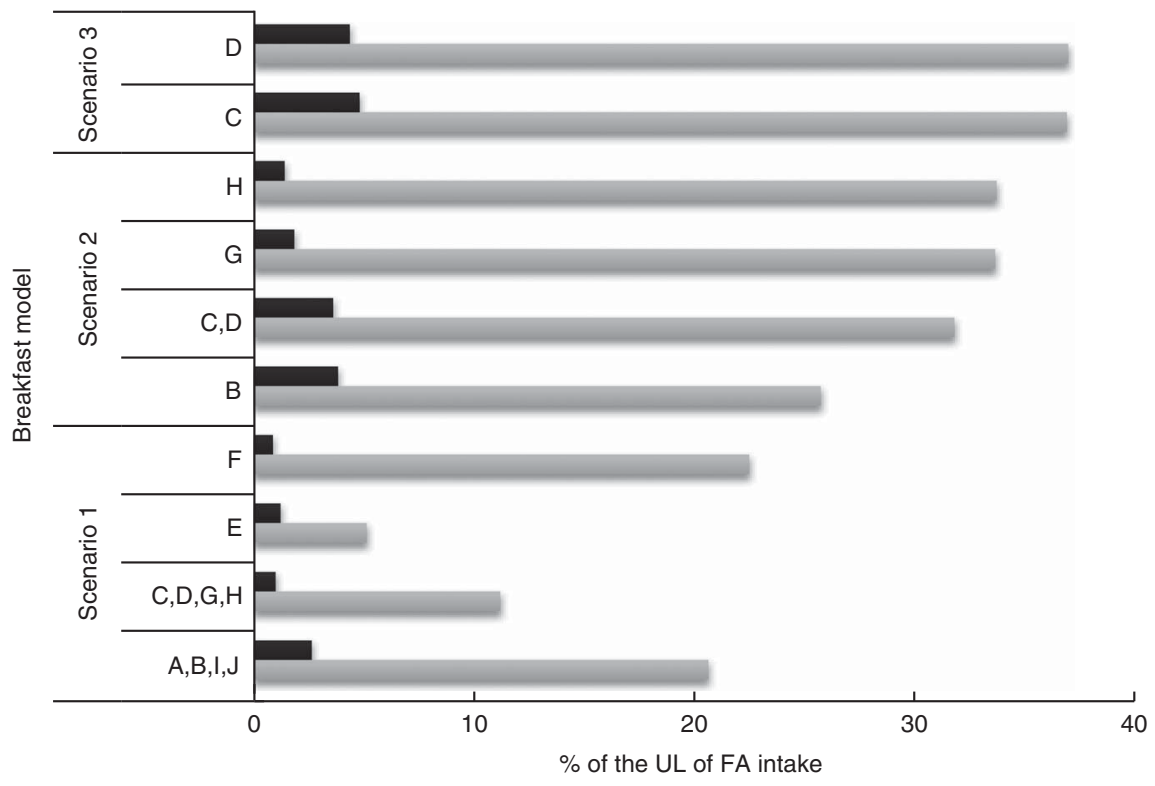

Fig. 3 Scenarios 1, 2 and 3: percentage contributions of foods fortified with folic acid (FA) in different breakfast models to the Upper

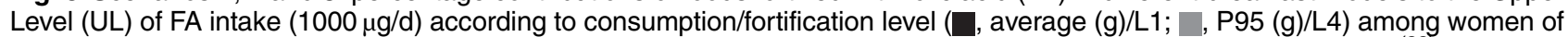
childbearing age (16-49 years), Madrid Region, Spain. Average, average level of consumption for the fortified product ${ }^{(22)}$; P95, 95th percentile of consumption for the fortified product ${ }^{(22)}$; L1 (level 1), $\leq 33 \mu \mathrm{g} \mathrm{FA/serving} \mathrm{(} \leq 16 \%$ of the Daily Reference Intake (DRI, $200 \mu \mathrm{g}$ ) for FA per serving as declared by manufacturers); L4 (level 4 ), $\geq 70 \mu \mathrm{g} \mathrm{FA/serving} \mathrm{(} \geq 35 \%$ of the DRI) ${ }^{(21)}$

mainly children and adolescents are becoming 'breakfast skippers $^{(15,31)}$. Also, a high percentage of the adult population declares to have just a cup of coffee with/without milk for breakfast ${ }^{(15)}$. Considering this fact, the effectiveness of breakfast product fortification could be limited. In the past few years, however, public health campaigns have been developed and implemented nationwide to promote daily breakfast intake ${ }^{(32)}$. For example, part of the Spanish Strategy for Nutrition, Physical Activity and Prevention of Obesity (NAOS Strategy), promoted by the Ministry of Health, Social Services and Equality, focused on the importance of a healthy breakfast within the goal of promoting healthy diets and preventing childhood obesity. Activities from NAOS included school visits throughout the country by trained nutrition educators, press releases, distribution of brochures and posters, and national television and radio commercials underlining the importance of the first meal of the day' and the food groups that should be included for a balanced breakfast (https://www.msssi. gob.es/en/campannas/campanas07/obesidad.htm). However, most of these campaigns were targeted at school-age children and therefore can have only limited impact on women. According to the literature, campaigns targeted to women of fertile age and counselling on FA importance is an area mainly concerning gynaecologists and other health-care practitioners such as pharmacists. In this regard, a review by Brito Garcia and Serra Majem ${ }^{(33)}$ on Spanish public health or policy actions to tackle micronutrient deficiencies underlines a lack of action by authorities when it comes to policy measures, including the case for FA awareness among women of childbearing age.
Research has shown that comprehensive nutritional labels on fortified food product packages can be essential tools for consumer education and, potentially, for the improvement of folate intakes ${ }^{(22,34)}$. In our studies we observed that a high percentage of the labels from FA-fortified products included a nutritional 'vitamin content claim' in compliance with European Regulations ${ }^{(21)}$. However, health claims linking FA with 'maternal tissue growth during pregnancy' ('effect on a normal pregnancy', as accepted by the European Food Safety Authority ${ }^{(35)}$ ) were included on only a minor proportion of these labels ${ }^{(9)}$. FA content of products must be included by regulation in the ingredients list and on the nutritional label as content per $100 \mathrm{~g}$ or $100 \mathrm{ml}$, additionally contents per food serving are also declared ${ }^{(21)}$; nevertheless, health claims are only voluntary at present. As such, food labelling can be useful for communicating nutritional and health messages to target populations; however, it seems that this is a largely missed opportunity in the case of the Spanish fortified products. A nutritional education approach that includes a description of nutrition labels, how to use their information, serving guidance and awareness of FA importance for women at periconceptional age are key issues to be undertaken by public health authorities and health professionals. In addition, manufacturers must provide consumers with relevant and clear information on their labels, according to the age or physiological target group (i.e. pregnancy, lactation, elderly, etc.). Women of childbearing age should be encouraged to include a balanced and varied breakfast meal on a daily basis in order to contribute to their overall energy and nutrient intakes and to comply with nutritional recommendations. 
A limitation of our study is that food intake throughout the day - whether fortified or not, which obviously may contribute to folate intake - was not taken into account. It could be expected that FA-fortified products in addition to the average daily intake of natural folate sources might reach women's recommended folate intake of $400 \mu \mathrm{g} / \mathrm{d}$. But national food consumption and diet assessment studies indicate this is not the case: folate requirements are not being met $^{(16,36)}$. Some authors emphasise that it is quite difficult to achieve the recommended folate intake through regular diet alone, as most foods commonly eaten are only low to moderate folate sources and the higher sources, such as liver and yeast extracts, are not eaten frequently or in amounts large enough to supply sufficient folate in the diet ${ }^{(37)}$. Furthermore, vitamin bioavailability is usually much lower in folate from natural sources when compared with synthetic FA. Folate intakes of the Spanish population have been evaluated in several studies (MAGRAMA $^{(16)}$, ENUCAM ${ }^{(36)}$, EnKid ${ }^{(38)}$ ) and potentially insufficient intakes were found in target and vulnerable groups such as women of childbearing age, children and the elderly. The average dietary folate intake in adult women was estimated to be approximately $250 \mu \mathrm{g} / \mathrm{d}$, i.e. the folate gap is roughly $150 \mu \mathrm{g} / \mathrm{d}^{(12)}$. Major dietary sources were green leafy vegetables and legumes. Nevertheless, to date there is no reliable information on the impact of voluntarily fortified food consumption and total FA intakes are probably being underestimated. The assessment of micronutrient intakes from fortified foodstuffs was described as a difficult task due to the relative absence of compositional data in tables and food composition databases ${ }^{(10)}$ and the rapidly growing market for these products. Our previous study showed that the availability of voluntarily FA-fortified products is widespread on the Spanish market and that different vitamin amounts are being added to diverse food groups by manufacturers ${ }^{(9)}$. In addition, consumer choice is overwhelmed by a huge number of novel foods and recipes, namely convenience and 'ready-to-eat' foods that may include folate as natural source but also added FA. Analytical folate data from a representative number of fresh-cut green-leaf products and ready-to-eat meal samples were recently reviewed by Fajardo et $a l .{ }^{(39)}$, these foodstuffs represent an important number of dietary sources that contribute to overall folate intakes. Food composition tables used in Spanish nutritional surveys include only a limited number of FA-fortified products, mainly RTEC. Fortification levels in the present study were established according to the European Regulations ${ }^{(21)}$ that include FA 'Daily Reference Intakes' (DRI, 200 $\mu \mathrm{g}$ ) as guidance for nutritional labelling. Noteworthy, in Spain, women's folate recommendation actually duplicates the DRI value. In addition, our previous studies showed that FA contents in food were higher than those declared on labels by manufacturers ('overages') ${ }^{(19)}$. Therefore, a more reliable approach was to use analytical instead of label FA data for the calculation of intakes. A suitable assessment of folate status is compelling, not only because suboptimal intakes of FA may be related to a deficiency condition, but also because adverse effects and risks after long-term exposure to high concentrations are not well known ${ }^{(7)}$.

In other European countries such as Ireland, voluntary fortification improved the dietary intake adequacy of a number of micronutrients, including FA, and did not contribute to excessive intakes within an adult's diet. Breakfast cereals and non-alcoholic beverages were the main fortified items consumed ${ }^{(40)}$. In The Netherlands, since 2007 there has been a maximum fortification level exemption for voluntarily FA-fortified products, which is set at $100 \mu \mathrm{g} / 418.6 \mathrm{~kJ}$ (100 kcal). Interestingly, it was established that at current food intake patterns of this country, this FA level is considered safe for adults and children $^{(41)}$. In Spain, however, voluntary fortification has not been evaluated recently. Back in 1998, Serra-Majem studied Spanish children's food and nutrient intakes. His findings revealed deficiencies for Fe, vitamin $\mathrm{C}$, vitamin $\mathrm{E}$, vitamin $\mathrm{D}$, folate and vitamin $\mathrm{B}_{6}^{(42)}$. The author concluded that the RNI for certain nutrients are difficult to achieve through consumption of unfortified foods. Further publications highlighted that fortified RTEC could make a significant contribution to children's mineral and vitamin requirements ${ }^{(43)}$.

\section{Conclusion}

At existing levels of voluntary FA food fortification on the Spanish market, the inclusion of FA-fortified products as part of a breakfast meal could positively impact the nutritional quality of the diet of fertile women without involving a risk for excessive FA exposure. Nevertheless, with the aim of making adequate food choices, nutritional education strategies that include FA food fortification within the context of a healthy diet is a priority issue that needs to be undertaken by public health authorities. Further studies are required to design, monitor and validate strategies to improve folate and FA intakes of fertile women.

\section{Acknowledgements}

Acknowledgements: The authors thank Paul Finglas, Jenny Plumb and Anthony Wright from the Institute of Food Research, Norwich, UK, and Rosalía Poó-Prieto from CEU San Pablo University, Madrid, Spain, for assistance with method development, food composition database development and helpful comments. Financial support: This work was funded by the Spanish Ministry of Education and Science (grant number AGL2005-06957: 'Folic acid content and bioavailability in fortified foods in Spain. Impact on folate intake in population groups at risk and 
evaluation as potential functional foods'). The Spanish Ministry of Education and Science had no role in the design, analysis or writing of this article. Conflict of interest: None. Authorship: The study was designed by G.V.-M. and E.A.-A.; M.L.S.-V. carried out the analyses and article writing. All authors contributed in interpreting the data and critically reviewing the manuscript. Ethics of buman subject participation: Ethical approval was not required for this study.

\section{References}

1. Blakley R (1969) The Biochemistry of Folic Acid and Related Pteridines. Amsterdam: North-Holland Publishing Company.

2. Medical Research Council Vitamin Study Research Group (1991) Prevention of neural tube defects: results of the Medical Research Council Vitamin Study. Lancet 338, 131-137.

3. Czeizel AE, Dudás I, Paput L et al. (2011) Prevention of neural-tube defects with periconceptional folic acid, methylfolate, or multivitamins? Ann Nutr Metab 58, 263-271.

4. World Health Organization \& Food and Agriculture Organization of the United Nations (2006) Guidelines on food fortification with micronutrients [L Allen, B de Benoist, O Dary et al., editors]. http://www.who.int/nutrition/publications/ micronutrients/guide_food_fortification_micronutrients.pdf (accessed May 2013).

5. Flour Fortification Initiative (2013) Wheat Flour Fortification Status - May 2013. Map of Global Progress. Countries With Mandatory Wheat Flour Fortification Regulations. http:// www.ffinetwork.org/global_progress/index.php (accessed May 2013).

6. Institute of Medicine, Food and Nutrition Board, Panel on Folate, Other B Vitamins and Choline (1998) Dietary Reference Intakes for Thiamin, Riboflavin, Niacin, Vitamin $B_{6}$, Folate, Vitamin $B_{12}$, Pantothenic Acid, Biotin, and Choline. Washington, DC: National Academy Press.

7. European Food Safety Authority (2009) ESCO report prepared by the EFSA Scientific Cooperation Working Group on Analysis of Risks and Benefits of Fortification of Food with Folic Acid. http://www.efsa.europa.eu/fr/supporting/ pub/3e.htm (accessed May 2010).

8. Verkaik-Kloosterman J, Tijhuis MJ, Beukers M et al. (2009) Evaluation of the Dutch Legislation on Food Fortification with Folic Acid and Vitamin D; Focus on Young Children. Bilthoven: National Institute for Public Health and the Environment (RIVM).

9. Samaniego-Vaesken ML, Alonso-Aperte E \& Varela-Moreiras G (2009) Folic acid fortified foods available in Spain: type of products, level of fortification and target population groups. Nutr Hosp 24, 459-466.

10. Bouckaert K, Slimani N, Nicolas G et al. (2011) Critical evaluation of folate data in European and international databases: recommendations for standardization in international nutritional studies. Mol Nutr Food Res 55, 166-180.

11. Samaniego-Vaesken ML, Alonso-Aperte E \& Varela-Moreiras G (2010) Analysis and evaluation of voluntary folic acid fortification of breakfast cereals in the Spanish market. J Food Compost Anal 23, 419-423.

12. Varela-Moreiras G, Avila JM, Cuadrado C et al. (2010) Evaluation of food consumption and dietary patterns in Spain by the Food Consumption Survey: updated information. Eur J Clin Nutr 64, Suppl. 3, S37-S43.

13. León-Muñoz LM, Guallar-Castillón P, Graciani A et al. (2012) Adherence to the Mediterranean diet pattern has declined in Spanish adults. J Nutr 142, 1843-1850.
14. Bitzer J, von Stenglin A \& Bannemerschult R (2013) Women's awareness and periconceptional use of folic acid: data from a large European survey. Int J Womens Health 5, 201-213.

15. Ministerio de Agricultura, Pesca y Alimentación MAGRAMA (2006) Qué desayunan los españoles? Observatorio del consumo y la distribución alimentaria. http://www.marm. es/es/alimentacion/temas/consumo-y-comercializacion-ydistribucion-alimentaria/desayuno_espanoles_tcm7-7939.pdf (accessed June 2013).

16. Varela-Moreiras G, Ávila J, Cuadrado C et al. (2012) Valoración Nutricional de la Dieta Española de acuerdo al Panel de Consumo Alimentario. http://www.fen.org.es/ imgPublicaciones/30092012125258.pdf (accessed May 2013).

17. Deshmukh-Taskar PR, Radcliffe JD, Liu Y et al. (2010) Do breakfast skipping and breakfast type affect energy intake, nutrient intake, nutrient adequacy, and diet quality in young adults? NHANES 1999-2002. J Am Coll Nutr 29, 407-418.

18. Dapcich V, Salvador Castell G, Ribas Barba L et al. (2004) Guía de la Alimentación Saludable. http://www.aesan. msc.es/AESAN/docs/docs/come_seguro_y_saludable/guia_ alimentacion2.pdf (accessed June 2013).

19. Samaniego-Vaesken ML (2013) Folic acid food fortification in Spain: food composition database, folic acid and folate analysis and predicted contribution to dietary reference intakes. Doctoral Thesis, Universidad San Pablo-CEU; available at http://hdl.handle.net/10637/5627

20. Moreiras O, Carvajal A, Cabrera L et al. (2013) Tablas de Composición de Alimentos, $16^{\mathrm{a}}$ ed. Madrid: Pirámide.

21. The European Parliament \& The Council of the European Union (2011) Regulation (EU) No 1169/2011 of the European Parliament and of the Council of 25 October 2011 on the provision of food information to consumers, amending Regulations (EC) No 1924/2006 and (EC) No $1925 / 2006$ of the European Parliament and of the Council, and repealing Commission Directive 87/250/EEC, Council Directive 90/496/EEC, Commission Directive 1999/10/EC, Directive 2000/13/EC of the European Parliament and of the Council, Commission Directives 2002/67/EC and 2008/5/EC and Commission Regulation (EC) No 608/2004. Official Journal of the European Union 22.11.2011, L304/18.

22. Buttriss J (2005) Strategies designed to increase awareness about folates and health, and to increase folate intake: a review. Trends Food Sci Technol 16, 246-252.

23. Moreiras O, Carvajal A, Cabrera L et al. (2011) Ingestas recomendadas de energía y nutrientes para la población española (revisadas y ampliadas 2011). Tablas de Composición de los Alimentos, $15^{\mathrm{a}}$ ed., pp. 228-229. Madrid: Pirámide and Departamento de Nutrición, Universidad Complutense de Madrid.

24. European Commission, Health \& Consumer Protection Directorate (2000) Opinion of the Scientific Committee on Food on the Tolerable Upper Intake Level of Folate; http:// ec.europa.eu/food/fs/sc/scf/out80e_en.pdf (accessed June 2009).

25. Martin JI, Landen WO, Soliman AM et al. (1990) Application of a tri-enzyme extraction for total folate determination in foods. J Assoc Off Anal Chem 73, 805-808.

26. Póo-Prieto R, Haytowitz DB, Holden JM et al. (2006) Use of the affinity/HPLC method for quantitative estimation of folic acid in enriched cereal-grain products. J Nutr 136, 3079-3083.

27. Bagley PJ \& Selhub J (2000) Analysis of folate form distribution by affinity followed by reversed-phase chromatography with electrochemical detection. Clin Chem $\mathbf{4 6}$, 404-411.

28. Sharpless K, Schiller S, Margolis S et al. (1997) Certification of nutrients in Standard Reference Material 1846: infant formula. J AOAC Int 80, 611-621. 
29. National Institute for Biological Standards and Control (2008) WHO International Standard Vitamin $\mathrm{B}_{12}$ And Serum Folate, NIBSC code: 03/178 Instructions for use (Version 2.0, Dated 04/04/2008). http://www.nibsc.org/documents/ifu/ 03-178.pdf (accessed February 2013).

30. Rampersaud GC, Pereira MA, Girard BL et al. (2005) Breakfast habits, nutritional status, body weight, and academic performance in children and adolescents. $J$ Am Diet Assoc 105, 743-760.

31. Serra-Majem L, Ribas L, Pérez-Rodrigo C et al. (2002) Determinants of nutrient intake among children and adolescents: results from the enKid study. Ann Nutr Metab $\mathbf{4 6}$, Suppl. 1, 31-38.

32. Ministerio de Sanidad, Servicios Sociales e Igualdad (2007) Campaña de prevención de la obesidad infantil ‘ ¿Despierta desayuna!' https://www.msssi.gob.es/campannas/campanas06/ obesidadInfant5.htm (accessed December 2013).

33. Brito García N \& Serra Majem L (2012) Micronutrient recommendations and policies in Spain: the cases of iodine, folic acid and vitamin D. Nutr Hosp 27, 1610-1618.

34. Cowburn G \& Stockley L (2005) Consumer understanding and use of nutrition labelling: a systematic review. Public Health Nutr 8, 21-28.

35. European Food Standards Authority, Panel on Dietetic Products, Nutrition and Allergies (2009) Scientific Opinion on the substantiation of health claims related to folate and blood formation (ID 79), homocysteine metabolism (ID 80), energy-yielding metabolism (ID 90), function of the immune system (ID 91), function of blood vessels (ID 94, 175, 192), cell division (ID 193), and maternal tissue growth during pregnancy (ID 2882) pursuant to Article 13(1) of Regulation (EC) No 1924/2006 on request from the European Commission. EFSA J 7, 1213-1235.
36. Ruiz Moreno E, Del Pozo de la Calle S, Cuadrado C, et al. (2014) Encuesta de Nutrición de la Comunidad de Madrid, ENUCAM 2009-2010. Documentos Técnicos de Salud Pública, Comunidad de Madrid (In the Press).

37. Abraham B \& Webb K (2001) Interim evaluation of the voluntary folate fortification policy. Australian Food and Nutrition Monitoring Unit, The National Food and Nutrition Monitoring and Surveillance Project, The Commonwealth Department of Health and Aged Care. http://www.health.gov. au/internet/main/publishing.nsf/Content/84026385A0EC6DC9 CA256F190004C8E1/\$File/folate.pdf (accessed May 2013).

38. Aranceta Bartrina J \& Serra-Majem L (2000) Hábitos alimentarios y consumo de alimentos en la población infantil y juvenil española (1998-2000). Estudio enKid. Barcelona: Masson.

39. Fajardo V, Alonso-Aperte E \& Varela-Moreiras G (2012) Lack of data on folate in convenience foods: should ready-to-eat products be considered relevant for folate intake? The European challenge. J Food Compost Anal 28, $155-163$.

40. Hannon EM, Kiely M \& Flynn A (2007) The impact of voluntary fortification of foods on micronutrient intakes in Irish adults. Br J Nutr 97, 1177-1186.

41. Verkaik-Kloosterman J, Beukers M, Buurma-Rethans E et al. (2012) Evaluation of the Dutch general exemption level for voluntary fortification with folic acid. Food Nutr Res 2012, 56.

42. Serra-Majem L (2001) Vitamin and mineral intakes in European children. Is food fortification needed? Public Health Nutr 4, 101-107.

43. Serra-Majem L, García-Closas R, Ribas Barba L et al. (2001) Food patterns of Spanish schoolchildren and adolescents: the enKid Study. Public Health Nutr 4, 1433-1438. 